\title{
Screening of Brazilian soybean genotypes with high potential for somatic embryogenesis and plant regeneration
}

\author{
Annette Droste(1), Anelise Machado da Silva( ${ }^{(3)}$, Iliane Freitas de Souza(2), Beatriz Wiebke-Strohm ${ }^{(3)}$, \\ Lauro Bücker-Neto ${ }^{(3)}$, Marta Bencke ${ }^{(3)}$, Márcia Viviane Sauner ${ }^{(2)}$ and Maria Helena Bodanese-Zanettini( ${ }^{(3)}$ \\ (1)Universidade Feevale, RS-239, № 2.755, CEP 93352-000 Novo Hamburgo, RS, Brazil. E-mail: annette@feevale.br (2)Universidade do Vale do \\ Rio dos Sinos, Avenida Unisinos 950, CEP 93022-000 São Leopoldo, RS, Brazil. E-mail: ilianesouza@yahoo.com.br, laurobucker@gmail.com, \\ mbencke@gmail.com, marcinhabio@hotmail.com ${ }^{(3)}$ Universidade Federal do Rio Grande do Sul, Instituto de Biociências, Departamento \\ de Genética, Caixa Postal 15.053, CEP 91501-970 Porto Alegre, RS, Brazil. E-mail: anesilva80@hotmail.com, strohm@sinos.net, \\ maria.zanettini@ufrgs.br
}

\begin{abstract}
The aim of this work was to identify Brazilian soybean (Glycine max) genotypes with potential to respond to in vitro culture stimuli for primary somatic embryo induction, secondary embryo proliferation and plant regeneration. Differences among eight tested cultivars were observed at each stage. Two cultivars, IAS-5 and BRSMG 68 Vencedora, were selected for the evaluation of the capacity for embryo differentiation and plant regeneration. These cultivars had high embryo induction frequencies, repetitive embryogenic proliferation, and low precocious embryo germination in the initial experiment. The effect of abscisic acid (ABA) and charcoal addition on plant regeneration was investigated. The addition of ABA to proliferation medium and of ABA and activated charcoal to maturation medium increased embryo differentiation rates, which resulted in a higher number of regenerated plants. The BRSMG 68 Vencedora cultivar was found to have a high potential for embryo induction, embryo proliferation and plant regeneration. The potential of this cultivar for somatic embryogenesis was similar to that observed for cultivar IAS-5, which is currently used for soybean transformation in Brazil. BRSMG 68 Vencedora may be a good alternative genotype for soybean genetic engineering via somatic embryogenesis protocols.
\end{abstract}

Index terms: Glycine max, Brazilian cultivars, embryogenic potential, genetic engineering, soybean transformation.

\section{Seleção de genótipos brasileiros de soja com alto potencial para embriogênese somática e regeneração de plantas}

Resumo - O objetivo deste trabalho foi identificar cultivares brasileiras de soja (Glycine max) com capacidade de resposta aos estímulos da cultura in vitro para a indução de embriões somáticos primários, proliferação de embriões secundários e regeneração de plantas. Foram observadas diferenças para cada estádio entre as oito cultivares testadas. Foram selecionadas duas cultivares, 'IAS-5' e BRSMG 68 Vencedora, para avaliação do potencial dos embriões quanto à diferenciação e conversão em plantas. Essas cultivares tiveram altas taxas de indução, proliferação embriogênica repetitiva e baixa germinação precoce dos embriões, no experimento inicial. Foi investigado o efeito da adição de ácido abscísico (ABA) e carvão sobre a regeneração. Os resultados mostraram que a adição de $\mathrm{ABA}$ ao meio de proliferação e de ABA e carvão ativado ao meio de maturação aumentaram as taxas de diferenciação dos embriões, o que resultou em maior número de plantas regeneradas. A cultivar BRSMG 68 Vencedora foi identificada como genótipo com alto potencial para indução e proliferação de embriões, bem como para regeneração de plantas. O potencial dessa cultivar quanto à embriogênese somática foi similar ao observado para a cultivar IAS-5, atualmente utilizada para transformação de soja no Brasil. A BRSMG 68 Vencedora pode ser um genótipo alternativo para a engenharia genética de soja via protocolos de embriogênese somática.

Termos para indexação: Glycine max, cultivares brasileiras, potencial embriogênico, engenharia genética, transformação de soja.

\section{Introduction}

The absence of highly efficient regeneration procedures is one of the main limiting factors in gene transfer technology in soybean (Tomlin et al., 2002). Proliferating somatic embryos are one of the most suitable and convenient targets for soybean genetic manipulation (Sato et al., 1993; Droste et al., 2002; Homrich et al., 2008). Several studies have shown differences among soybean genotypes in their capacity to respond to the different steps of somatic embryogenesis (Bailey et al., 1993; Santos et al., 1997; Simmonds \& Donaldson, 2000; Droste et al., 2001; Tomlin et al., 2002; Hiraga et al., 2007; Yang

Pesq. agropec. bras., Brasília, v.45, n.7, p.715-720, jul. 2010 
et al., 2009). However, the development of genetically engineered soybean has been limited to a small number of cultivars that respond well to in vitro culture (Tomlin et al., 2002).

The efficiency of regeneration and transformation of soybean is genotype-dependent and remains effective mainly for the variety 'Jack' and a few other genotypes in the USA (Walker \& Parrott, 2001; Schmidt et al., 2005). In Brazil, the IAS-5 and Bragg cultivars have been used in transformation studies (Droste et al., 2002; Homrich et al., 2008).

The genotype-dependence justifies the screening of soybean cultivars that are more responsive to the induction of somatic embryogenesis and regeneration, including the new genotypes constantly produced by genetic engineering.

The objective of this study was to evaluate Brazilian soybean genotypes for their capacity to respond to embryogenesis induction, embryo proliferation and plant regeneration.

\section{Materials and Methods}

Bragg and IAS-5 are North American adapted cultivars, commonly used in genetic improvement programs, previously evaluated for their embryogenic response (Santos et al., 1997; Droste et al., 2001). They were used in the first experiment together with cultivars BRSMG 68 Vencedora, BRS Torena, BRS 137, BRS 154, Embrapa 48 and MG/BR 46 Conquista, developed and released by Brazilian breeding programs, and recommended for commercial growth in different states of Brazil (Brasil, 2009).

The culture procedure is illustrated in Figure 1. Young pods containing immature seeds of 3-4 mm in length were harvested from field-grown plants. Pod sterilization, cotyledon excision and placement on D40 induction medium (Bailey et al., 1993) were performed according to Droste et al. (2002). Six Petri dishes, containing ten pairs of cotyledons each, were prepared for each cultivar. Cultures were incubated at
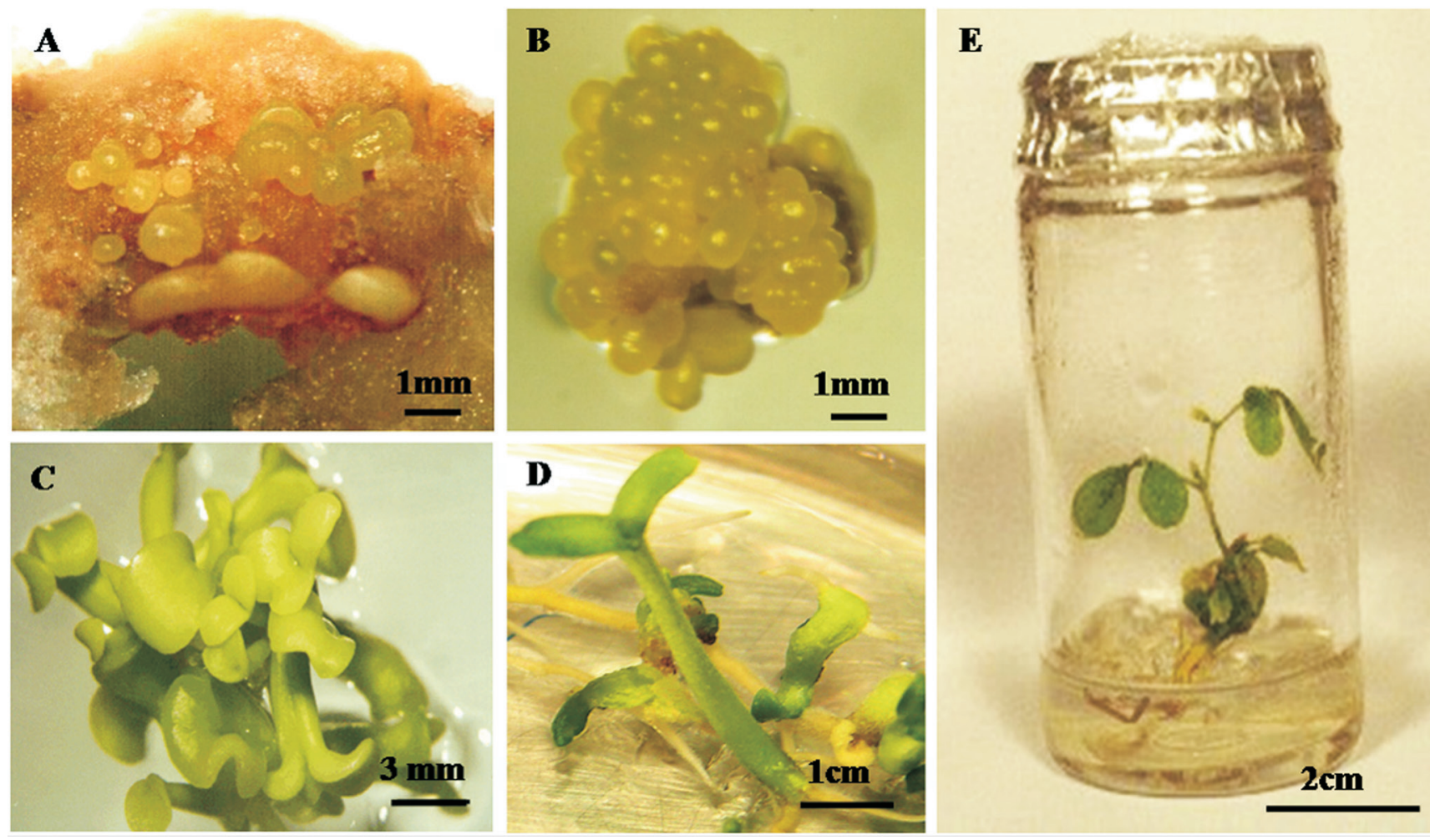

Figure 1. Soybean somatic embryo induction, proliferation and plant regeneration. A, primary somatic embryos induced from immature zygotic cotyledons; B, cluster of globular embryos on proliferation medium; C, cluster of histodifferentiated somatic embryos, after 30 days on maturation medium; D, somatic embryos germinating on conversion medium; E, regenerated plant. 
$26 \pm 1^{\circ} \mathrm{C}$ and $22.5 \mu \mathrm{E} \mathrm{m}^{2} \mathrm{~s}^{-1}$ light on a $16 / 8$ hour light/dark cycle for somatic embryogenesis induction.

After 30 days on the induction medium, the cotyledons with primary somatic embryos were transferred to D20 proliferation medium (Wright et al., 1991). After 20 more days, dishes were scored for percentage of embryogenic cotyledon pairs and number of somatic embryos per cotyledon pair. Somatic embryo clusters were then removed from the cotyledons and transferred to fresh proliferation medium, in which they were maintained for five months with subcultures every 14 days.

In order to evaluate the proliferation capacity, a set of four clusters of secondary somatic embryos at the initial globular stage, with $2-3 \mathrm{~mm}$ in diameter each, were weighted as a unit and placed in $60 \times 15-\mathrm{mm}$ Petri dishes containing proliferation medium. Five dishes were used for each cultivar. After 28 days, with a subculture on the $14^{\text {th }}$ day, the weight of the four clusters in each Petri dish was again recorded. The response to proliferability was the weight gain (mg), calculated as the difference between the initial and final weights.

To induce histodifferentiation, clusters of proliferating embryogenic tissue, with $2-3 \mathrm{~mm}$ in diameter, were placed on modified MSM6 maturation medium (Finer \& McMullen, 1991), containing MS salts (Murashige \& Skoog, 1962), B5 vitamins (Gamborg et al., 1968), 6\% sucrose, $0.3 \%$ Phytagel, at $\mathrm{pH} 6.4$, before autoclaving. Four embryogenic clusters were placed in each Petri dish, and four dishes were used per cultivar. After four weeks, the embryos were separated and transferred to fresh maturation medium for four more weeks. The number of histodifferentiated embryos and the number of precociously germinated embryos was recorded. Precocious germination refers to germination of embryos on maturation medium, i.e., before their desiccation and transfer to conversion medium.

In a second experiment, the IAS-5 and BRSMG 68 Vencedora cultivars were selected for evaluation of germination and conversion capacities. Abscisic acid (ABA) at $50 \mu \mathrm{mol} \mathrm{L}-1$ was added to D20 proliferation medium in the last month, before the embryo clusters were transferred to maturation medium. ABA concentration was based on a previous study, which showed that globular embryos treated with ABA have higher conversion capability than untreated ones (Weber et al., 2007). Sixteen clusters of secondary somatic embryos at the initial globular stage, of each cultivar, were distributed in four Petri dishes containing proliferation medium with ABA. The same number of embryo clusters was placed on proliferation medium without ABA (control). After 30 days, the embryo clusters treated with ABA were transferred to MSM6 maturation medium with $\mathrm{ABA}$ at $50 \mu \mathrm{mol} \mathrm{L} \mathrm{L}^{-1}$ and $0.5 \%$ activated charcoal (Bailey et al., 1993). The untreated embryo clusters were transferred to MSM6 medium without ABA and charcoal (control). After 30 days in the maturation medium, the treated and the untreated histodifferentiated embryos were individually transferred to fresh MSM6 medium free of ABA and charcoal for four more weeks. A sample of 100 histodifferentiated nonprecociously germinated embryos per cultivar was randomly picked and placed in dry, sterile dishes for a 2-day desiccation treatment. Partially desiccated embryos were plated on MSO conversion medium, containing MS salts, B5 vitamins, 3\% sucrose, $0.3 \%$ Phytagel, at $\mathrm{pH}$ 6.4, before autoclaving. After 45 days in the conversion medium, the number of germinated embryos and converted plants were scored. Germination refers to root and shoot emission, while conversion was recorded as the development of the branched root and formation of at least one trifoliolate leaf (Walker \& Parrott, 2001).

Data on somatic embryo induction were analyzed using the nonparametric Kruskal-Wallis analysis of variance. Pairwise multiple comparisons of ranked data were performed to compare cultivars, at the 5\% significance level. Data obtained for proliferation and histodifferentiation capacity were submitted to ANOVA (Zar, 1999).

\section{Results and Discussion}

Somatic embryos were induced in all genotypes (Table 1). The embryogenic potential expressed as the number of somatic embryos per cotyledon pair

Table 1. Capacity to produce somatic embryos from immature cotyledon pairs of eight Brazilian soybean cultivars ${ }^{(1)}$.

\begin{tabular}{lcc}
\hline Cultivar & $\begin{array}{c}\text { Percentage of embryogenic } \\
\text { cotyledon pair }\end{array}$ & $\begin{array}{c}\text { Somatic embryos } \\
\text { per cotyledon pair }\end{array}$ \\
\hline Bragg & $41.7 \pm 19.4$ & $2.2 \pm 1.5 \mathrm{~b}$ \\
BRSMG 68 Vencedora & $66.2 \pm 39.5$ & $6.6 \pm 5.8 \mathrm{a}$ \\
BRS Torena & $52.2 \pm 22.3$ & $1.3 \pm 1.2 \mathrm{~b}$ \\
BRS 137 & $38.7 \pm 17.6$ & $0.9 \pm 1.0 \mathrm{~b}$ \\
BRS 154 & $52.2 \pm 22.3$ & $2.5 \pm 1.5 \mathrm{~b}$ \\
Embrapa 48 & $40.0 \pm 21.0$ & $1.0 \pm 1.0 \mathrm{~b}$ \\
IAS5 & $70.0 \pm 22.8$ & $10.6 \pm 6.6 \mathrm{a}$ \\
MG/BR 46 Conquista & $64.0 \pm 18.2$ & $8.3 \pm 2.4 \mathrm{a}$ \\
\hline (1)Mean \pm SD followed by equal letters in the columns do not differ by \\
multiple comparison tests, at 5\% probability.
\end{tabular}

Pesq. agropec. bras., Brasília, v.45, n.7, p.715-720, jul. 2010 
varied significantly among cultivars, and IAS-5, BRSMG 68 Vencedora, and MG/BR 46 Conquista produced thehighestmeannumbers $(\mathrm{p}<0.001)$. Previous studies also reported the high capacity of IAS-5 to produce somatic embryos (Santos et al., 1997; Di Mauro et al., 2000; Droste et al., 2001). This is the first report on the embryogenic potential of cultivars BRSMG 68 Vencedora, BRS Torena, BRS 137, BRS 154, Embrapa 48 and MG/BR 46 Conquista. In soybean, differences among cultivars in capacity to produce somatic embryos from immature cotyledons have been shown in several reports (Komatsuda \& Ohyama, 1988; Bailey et al., 1993; Santos et al., 1997; Di Mauro et al., 2000; Simmonds \& Donaldson, 2000; Droste et al., 2001; Meurer et al., 2001; Tomlin et al., 2002; Hofmann et al., 2004; Hiraga et al., 2007; Yang et al., 2009).

A clear influence of the genotype on the capacity for repeated embryogenesis was also detected. Proliferative cultures could not be established for cultivars BRS Torena and BRS 137. However, continuous proliferation was obtained for Bragg, BRSMG 68 Vencedora, BRS 154, Embrapa 48, IAS-5 and MG/BR 46 Conquista, after five months in the proliferation medium. The growth rate of the embryogenic tissues in a 28-day period is presented in Table 2. All analyzed cultivars showed embryogenic proliferation capacity. Although no significant differences were observed among cultivars, MG/BR 46 Conquista had a relatively lower growth rate.

Proliferative embryogenic cultures were established for the Bragg, BRS 154 and Embrapa 48 cultivars, despite their low capacity for somatic embryo induction (Table 1). The absence of correlation between somatic embryo induction and repetitive proliferation of embryogenic cultures has been previously reported

Table 2. Weight gain (mean \pm SD) of embryogenic tissue after 28-day subculture period.

\begin{tabular}{lccc}
\hline Cultivar & $\begin{array}{c}\text { Initial weight } \\
(\mathrm{mg})\end{array}$ & $\begin{array}{c}\text { Final weight } \\
(\mathrm{mg})\end{array}$ & $\begin{array}{c}\text { Growth } \\
\text { rate }^{(1)}\end{array}$ \\
\hline Bragg & $35.1 \pm 6.3$ & $125.3 \pm 33.6$ & $3.5 \pm 0.4$ \\
BRSMG 68 Vencedora & $29.1 \pm 2.9$ & $117.3 \pm 40.8$ & $4.0 \pm 1.3$ \\
BRS 154 & $40.1 \pm 12.7$ & $179.9 \pm 36.2$ & $4.9 \pm 1.6$ \\
Embrapa 48 & $34.4 \pm 7.2$ & $119.9 \pm 47.3$ & $3.5 \pm 1.1$ \\
IAS5 & $24.9 \pm 4.5$ & $93.5 \pm 22.8$ & $3.9 \pm 1.2$ \\
MG/BR46 Conquista & $30.8 \pm 4.7$ & $76.7 \pm 29.9$ & $2.6 \pm 1.4$ \\
\hline (1) & & &
\end{tabular}

${ }^{(1)}$ Quotient between final and initial weight.
(Bailey et al., 1993; Simmonds \& Donaldson, 2000; Droste et al., 2001; Yang et al., 2009).

The highest number of histodifferentiated embryos was obtained for the cultivar BRSMG 68 Vencedora, while MG/BR 46 Conquista had the lowest number (Table 3). All cultivars showed precocious germination, and MG/BR 46 Conquista showed the highest germination percentage (34\%). Embryos that germinate before sufficient maturation often display poor development and reduced plant regeneration (Merkle et al., 1995). Therefore, certain cultivars, such as MG/BR 46 Conquista, must be discarded as candidates for successful embryogenesis.

In previous studies on soybean, ABA was considered to promote embryo growth, development, maturation, and improved embryo germination, when used in the globular stage (Tian \& Brown, 2000), while ABA supplied during advanced maturation did not increment conversion frequencies (Schmidt et al., 2005). However, Weber et al. (2007) reported an increment on plant conversion when ABA was employed in both proliferation and maturation stages.

When added to the medium, activated charcoal presumably adsorbs auxins released from developing tissues and may promote a more normal morphology and increased germination ability (Merkle et al., 1995). Combination of ABA and activated charcoal has been observed to be beneficial for the development of Picea abies somatic embryos (Pullman et al., 2005).

For both cultivars tested, the addition of ABA and activated charcoal to the medium increased the number of histodifferentiated embryos (Table 4). The percentage of converted plants obtained for cultivar BRSMG 68 Vencedora (45\%) was slightly higher than that of cultivar IAS-5 (42\%), currently used for soybean transformation in Brazil (Droste et al., 2001, 2002; Homrich et al., 2008). In a previous experiment,

Table 3. Histodifferentiation and precocious germination after two months in maturation medium.

\begin{tabular}{lcc}
\hline Cultivar & $\begin{array}{c}\text { Histodifferentiated } \\
\text { embryos }\end{array}$ & $\begin{array}{c}\text { Precociously germinated } \\
\text { embryos }(\%)^{(1)}\end{array}$ \\
\hline Bragg & 700 & 6.1 \\
BRSMG 68 Vencedora & 819 & 16.2 \\
BRS 154 & 473 & 19.7 \\
Embrapa 48 & 565 & 11.0 \\
IAS5 & 531 & 5.7 \\
MG/BR46 Conquista & 119 & 34.5 \\
(1)Percentage refers to the number of germinated embryos over the total of \\
histodifferentiated embryos.
\end{tabular}


Table 4. Number of histodifferentiated embryos and percentage of converted plants from soybean cultivars IAS-5 and BRSMG 68 Vencedora after different maturation conditions.

\begin{tabular}{lccc}
\hline Cultivar & Treatment & $\begin{array}{c}\text { Number of } \\
\text { histodifferentiated embryos }\end{array}$ & $\begin{array}{r}\text { Regenerated } \\
\text { plants (\%) }\end{array}$ \\
\hline \multirow{2}{*}{ BRSMG 68 } & ABA/charcoal & 1,247 & 45 \\
& control & 627 & 42 \\
\multirow{2}{*}{ IAS-5 } & ABA/charcoal & 1,138 & 42 \\
& control & 715 & 31 \\
\hline
\end{tabular}

in which $\mathrm{ABA}$ was added to the proliferation and maturation medium, Weber et al. (2007) obtained the same conversion frequency (42\%) for cultivar IAS-5.

Considering the number of histodifferentiated embryos and the conversion percentage obtained in the present work, it is possible to estimate the expected number of plants for each treatment (Table 4). The increment of histodifferentiated embryos obtained from the $\mathrm{ABA} /$ charcoal treatment represents a double probability for plant regeneration in transformation experiments.

This work identified BRSMG 68 Vencedora and confirmed IAS-5 as genotypes with high potential for somatic embryogenesis and plant regeneration. Selection of such cultivars should provide a reasonable probability of success at any laboratory initiating soybean embryogenic protocols.

\section{Conclusions}

1. Cultivar BRSMG 68 Vencedora and IAS-5 are suitable genotypes for successful embryogenesis and transformation.

2. Addition of ABA to proliferation medium and of ABA plus activated charcoal to maturation medium increases embryo histodifferentiation, resulting in a higher percentage of regenerated plants.

\section{Acknowledgements}

To Conselho Nacional de Desenvolvimento Científico e Tecnológico, Fundação de Amparo à Pesquisa do Estado do Rio Grande do Sul, Coordenação de Aperfeiçoamento de Pessoal de Nível Superior and Centro do Agronegócio - Casa Rural, for financial support; to Scatter Consultoria em Estatística, for the assistance in the statistical analysis.

\section{References}

BAILEY, M.A.; BOERMA, H.R.; PARROTT, W.A. Genotype effects on proliferative embryogenesis and plant regeneration of soybean. In Vitro Cellular and Developmental Biology, v.29, p.102-108, 1993.

BRASIL. Ministério da Agricultura, Pecuária e Abastecimento. Zoneamento agrícola de risco climático: cultivares de soja ano-safra 2008/2009. Available at: <www.agricultura.gov.br>. Accessed on: 04 Nov. 2009.

DI MAURO, A.O.; NOBREGA, J.C.M. de; DI MAURO, S.M.Z.; COLLINS, G.B. Interactions in the Agrobacterium-soybean system and capability of some Brazilian soybean cultivars to produce somatic embryos. Genetics and Molecular Biology, v.23, p.217-220, 2000.

DROSTE, A.; LEITE, P.C.P.; PASQUALI, G.; MUNDSTOCK, E.C.; BODANESE-ZANETTINI, M.H. Regeneration of soybean via embryogenic suspension culture. Scientia Agricola, v.58, p.753-758, 2001.

DROSTE, A.; PASQUALI, G.; BODANESE-ZANETTINI, M.H. Transgenic fertile plants of soybean [Glycine $\max (\mathrm{L}$.) Merrill] obtained from bombarded embryogenic tissue. Euphytica, v.127, p.367-376, 2002.

FINER, J.J.; MCMULLEN, M.D. Transformation of soybean via particle bombardment of embryogenic suspension culture tissues. In Vitro Cellular and Developmental Biology, v.27, p.175-182, 1991.

GAMBORG, O.L.; MILlER, R.A.; OJIMA, K. Nutrient requirements of suspension cultures of soybean root cells. Experimental Cell Research, v.50, p.151-158, 1968.

HIRAGA, S.; MINAKAWA, H.; TAKAHASHI, K.; TAKAHASHI, R.; HAJIKA, M.; HARADA, K.; OHTSUBO, N. Evaluation of somatic embryogenesis from immature cotyledons of Japanese soybean cultivars. Plant Biotechnology, v.24, p.435-440, 2007.

HOFMANN, N.E.; NELSON, R.L.; KORBAN, S.S. Influence of media components and $\mathrm{PH}$ on somatic embryo induction in three genotypes of soybean. Plant Cell, Tissue and Organ Culture, v.77, p.157-163, 2004.

HOMRICH, M.S.; PASSAGLIA, L.M.P.; PEREIRA, J.F.; BERTAGNOLLI, P.F.; PASQUALI, G.; ZAIDI, M.A.; ALTOSAAR, I.; BODANESE-ZANETTINI, M.H. Resistance to Anticarsia gemmatalis Hübner (Lepidoptera, Noctuidae) in transgenic soybean (Glycine max (L.) Merrill, Fabales, Fabaceae) cultivar IAS-5 expressing a modified Cry1 Ac endotoxin. Genetics and Molecular Biology, v.31, p.522-531, 2008.

KOMATSUDA, T.; OHYAMA, K. Genotype of high competence for somatic embryogenesis and plant regeneration in soybean Glycine max. Theoretical and Applied Genetics, v.75, p.695-700, 1988.

MERKLE, S.A.; PARROTT, W.A.; FLINN, B.S. Morphogenic aspects of somatic embryogenesis. In: THORPE, T.A. (Ed.). In vitro embryogenesis in plants. Dordrecht: Kluwer Academic, 1995. p.155-203. 
MEURER, C.A.; DINKINS, R.D.; REDMOND, C.T.; MCALLISTER, K.P.; TUCKER, D.T.; WALKER, D.R.; PARROTT, W.A.; TRICK, H.N.; ESSIG, J.S.; FRANTZ, H.M.; FINER, J.J.; COLLINS, G.B. Embryogenic response of multiple soybean [Glycine $\max (\mathrm{L}$.) Merr.] cultivars across three locations. In Vitro Cellular and Developmental Biology - Plant, v.37, p.62-67, 2001.

MURASHIGE, T.; SKOOG, F. A revised medium for rapid growth and bioassays with tobacco tissue cultures. Physiologia Plantarum, v.15, p.473-497, 1962.

PULLMAN, G.S.; GUPTA, P.K.; TIMMIS, R.; CARPENTER, C.; KREITINGER, M.; WELTY, E. Improved Norway spruce somatic embryo development through the use of abscisic acid combined with activated carbon. Plant Cell Reports, v.24, p.271- 279, 2005.

SATO, S.; NEWELL, C.; KOLACZ, K.; TREDO, L.; FINER, J.; HINCHEE, M. Stable transformation via particle bombardment in two different soybean regeneration systems. Plant Cell Reports, v.12, p.408-413, 1993.

SANTOS, K.G.B.; MUNDSTOCK, E.; BODANESE-ZANETTINI, M.H. Genotype-specific normalization of soybean somatic embryogenesis through the use of an ethylene inhibitor. Plant Cell Reports, v.16, p.859-864, 1997.

SCHMIDT, M.A.; TUCKER, D.M.; CAHOON, E.B.; PARROTT, W.A. Towards normalization of soybean somatic embryo maturation. Plant Cell Reports, v.24, p.383-391, 2005.

SIMMONDS, D.H.; DONALDSON, P.A. Genotype screening for proliferative embryogenesis and biolistic transformation of shortseason soybean genotypes. Plant Cell Reports, v.19, p.485-490, 2000.
TIAN, L.N.; BROWN, D.C.W. Improvement of soybean somatic embryo development and maturation by abscisic acid treatment. Canadian Journal of Plant Science, v.80, p.721-276, 2000.

TOMLIN, E.S.; BRANCH, S.R.; CHAMBERLAIN, D.; GABE, H.; WRIGHT, M.S.; STEWART JUNIOR, C.N. Screening of soybean, Glycine $\max (\mathrm{L}$.) Merrill, lines for somatic embryo induction and maturation capability from immature cotyledons. In Vitro Cellular and Developmental Biology - Plant, v.38, p.543-548, 2002.

WALKER, D.R.; PARROTT, W.A. Effect of polyethylene glycol and sugar alcohols on soybean somatic embryo germination and conversion. Plant Cell, Tissue and Organ Culture, v.64, p.55-62. 2001.

WEBER, R.L.M.; KÖRBES, A.P.; BALDASSO, D.A.; CALLEGARI-JACQUES, S.M.; BODANESE-ZANETTINI, M.H.; DROSTE, A. Beneficial effect of abscisic acid on soybean somatic embryo maturation and conversion into plants. Plant Cell Culture and Micropropagation, v.3, p.1-9, 2007.

WRIGHT, M.S.; LAUNIS, K.L.; NOVITZKY, R.; DUESING, J.H.; HARMS, C.T. A simple method for the recovery of multiple fertile plants from individual somatic embryos of soybean [Glycine $\max (\mathrm{L}$.) Merrill]. In Vitro Cellular and Developmental Biology - Plant, v.27, p.153-157, 1991.

YANG, C.; ZHAO, T.J.; YU, D.Y.; GAI, J. Somatic embryogenesis and plant regeneration in Chinese soybean (Glycine max (L.) Merr.) -impacts of mannitol, abscisic acid, and explant age. In Vitro Cellular and Developmental Biology - Plant, v.45, p.180-188, 2009.

ZAR, J.H. (Ed.) Biostatistical analysis. $4^{\text {th }}$ ed. New Jersey: Prentice Hall, 1999. 663p.

Received on April 20, 2010 and accepted on June 4, 2010 